Article

\title{
Baker's Yeast Mediated Reduction of 2-Acetyl-3-methyl Sulfolane
}

\author{
Rebecca E. Deasy ${ }^{1}$, Noreen O'Riordan ${ }^{1}$ and Anita R. Maguire ${ }^{2, *}$ \\ 1 Department of Chemistry, Analytical and Biological Chemistry Research Facility, \\ University College Cork, Cork, Ireland; E-Mails: rebeccadeasy@ucc.ie (R.E.D.); \\ lynch_noreen@1illy.com (N.O.) \\ 2 Department of Chemistry \& School of Pharmacy, Analytical and Biological Chemistry Research \\ Facility, Synthesis and Solid State Pharmaceutical Cluster, University College Cork, Cork, Ireland \\ * Author to whom correspondence should be addressed; E-Mail: a.maguire@ucc.ie; \\ Tel.: +353-21-490-1694/2125/3501; Fax: +353-21-490-1770.
}

Received: 14 February 2014; in revised form: 16 May 2014 / Accepted: 23 May 2014 /

Published: 18 June 2014

\begin{abstract}
The baker's yeast mediated reduction of 2-acetyl-3-methyl sulfolane $\mathbf{1}$ to provide the corresponding alcohol $\mathbf{2}$ is described. Excellent efficiency and enantioselectivity $(>98 \%$ ee) has been achieved under these mild environmentally benign reaction conditions. In direct contrast, the chemical reduction of $\mathbf{1}$ proceeds with poor yield $(\leq 25 \%)$ and diastereocontrol.
\end{abstract}

Keywords: baker's yeast (Saccharomyces cerevisiae); biocatalysis; asymmetric reduction; chiral alcohol; sulfolane

\section{Introduction}

One of the most widely studied and commercially significant whole cell systems employed in biocatalysis is baker's yeast (Saccharomyces cerevisiae), which has been extensively utilised in the asymmetric reduction of a wide variety of ketones. This is largely due to the ready availability, ease of experimental procedures and versatility of this microorganism [1-5]. Both the efficiency and stereoselectivity in baker's yeast mediated reduction of ketones is strongly influenced by both the presence and the position of sulfur substituents or indeed by the use of sulfur containing additives [6,7]. 
We have previously reported the successful optimisation of baker's yeast mediated reduction of 2-benzenesulfonyl substituted cyclopentanone and cyclohexanone derivatives to form the corresponding cycloalkanol in enantiopure form [8,9]. In addition, a viable route to the complementary enantiomeric series has been identified [10]. Base induced ring cleavage of the enantioenriched $\beta$-keto-sulfones has also been described to provide a synthetically viable route to enantioenriched novel carboxylic acids [10].

Leading on from the success of the enantioselective yeast reduction of cyclopentanones bearing $\alpha$-benzenesulfonyl groups, we extended this study to include a five-membered cyclic sulfone (sulfolane) substituted at the 2- and 3-positon. The cyclic sulfone moiety is an important pharmacophore in medicinal chemistry. The ring structure has been explored as the key chiral subunit and scaffold for the construction of biologically active molecules for example protease and $\beta$-lactamase inhibitors [11-15].

The sulfolane structure is similar to that of the previously reported 2-benzenesulfonyl substituted cyclopentanone, except the sulfonyl moiety is incorporated within the ring structure with the ketone functionality external to the ring (Figure 1). In terms of relative positioning of the ketone and sulfonyl moieties it could not be anticipated if the sulfolane would fit into the active site of the reductase to facilitate hydride delivery to the carbonyl group. Herein, we report our studies, exploring the mild baker's yeast mediated reduction of 2-acetyl-3-methyl sulfolane $\mathbf{1}$.

Figure 1. 2-Sulfonyl-3-methylcyclopentanone and 2-acetyl-3-methyl sulfolane $\mathbf{1 .}$

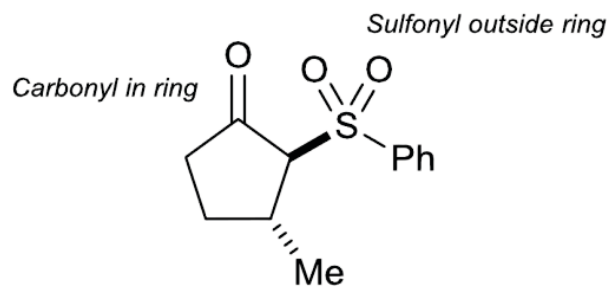

2-Sulfonyl-3-methylcyclopentanone

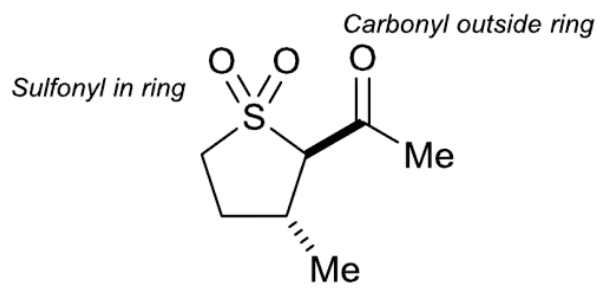

2-Acetyl-3-methyl sulfolane 1

\section{Results and Discussion}

\subsection{Preparation of trans-2-Acetyl-3-methyl Sulfolane 1}

The key to the synthesis of racemic trans-2-acetyl-3-methyl sulfolane 1, the desired substrate for baker's yeast mediated reduction, was the initial preparation of sulfonylpropanone $\mathbf{5}$ which encompassed the basic acyclic system with both functional groups in the required position [16,17]. Highly regioselective carbenoid $\mathrm{C}-\mathrm{H}$ insertion of $\alpha$-diazocarbonyl compounds mediated by rhodium(II) was chosen as an excellent synthetic route for the subsequent ring closure to provide the tetrahydro-thiophene system (Scheme 1).

The intermolecular rhodium(II) catalysed $\mathrm{C}-\mathrm{H}$ insertion reaction of $\alpha$-diazo- $\beta$-keto sulfones has been widely developed by Monteiro [18] and this synthetic methodology has been extensively employed in our group in the preparation of the 3-susbtituted-2-benzenesulfonylcyclopentanones [8-10]. In this study $\mathrm{Rh}_{2}$ (tfacam $)_{4}$ gave excellent regioselectivity in the remote functionalisation of the unactivated $\mathrm{C}-\mathrm{H}$ bond with one sulfolane diastereomer observed by ${ }^{1} \mathrm{H}$ NMR analysis. The relative stereochemistry of $\mathbf{1}$ was assigned as trans by NMR spectroscopy. 
Scheme 1. Synthesis of trans-2-acetyl-3-methyl sulfolane 1.

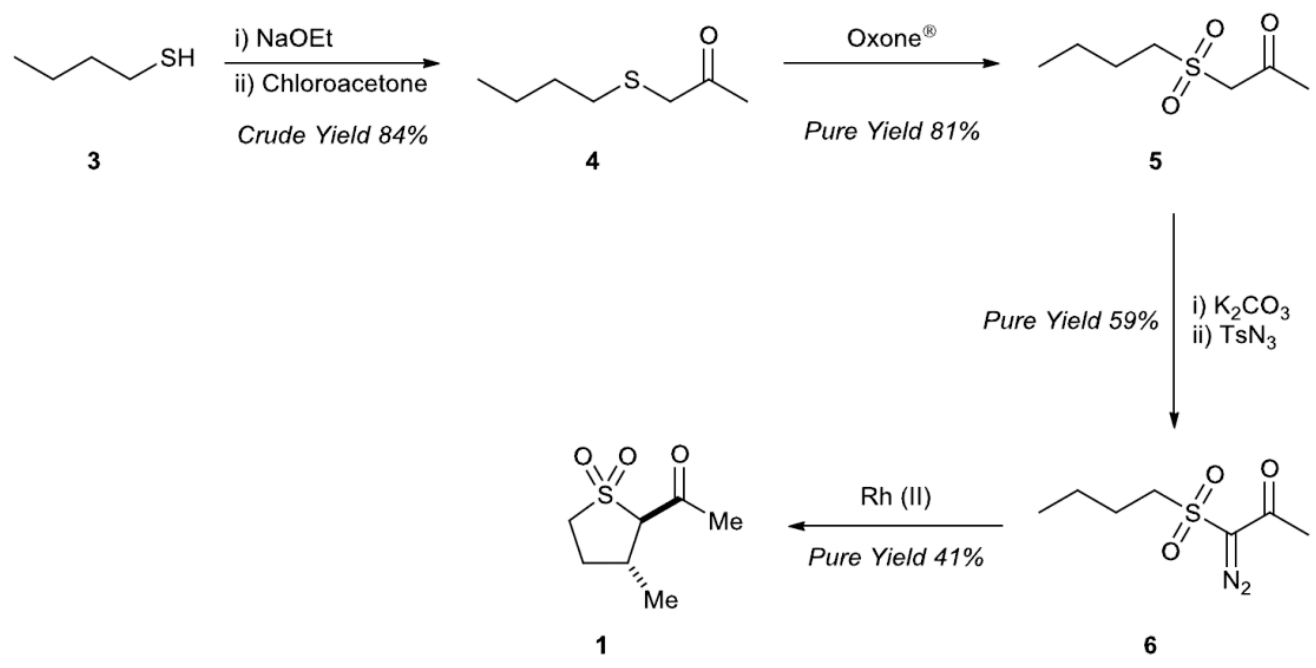

\subsection{Sodium Borohydride Reduction of trans-2-Acetyl-3-methyl Sulfolane 1}

Traditional sodium borohydride reduction of the diastereomerically pure trans-2-acetyl-3-methyl sulfolane 1 was remarkably inefficient. The recovered alcohol 2 was isolated in very low yield ((11\%-25\%), Table 1, entries 1-3). Significantly, when other reducing agents were investigated at various temperatures a similarly poor yield ((10\%-15\%), Table 1, entries 4-7) of alcohol 2 was recovered.

Table 1. Chemical reduction of trans-2-acetyl-3-methyl sulfolane $\mathbf{1 .}$

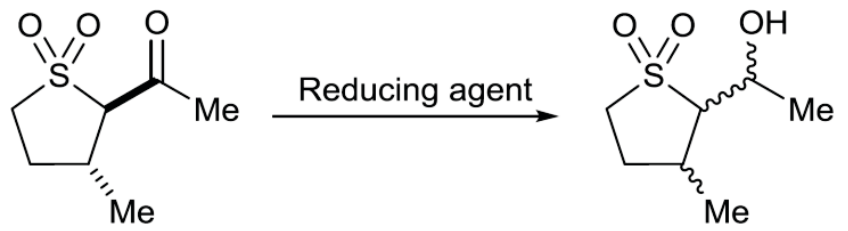

1

2

\begin{tabular}{cccc}
\hline Entry $^{\mathbf{a}}$ & Reducing Agent & Temperature & Yield 2 (\%) \\
\hline 1 & $\mathrm{NaBH}_{4} /$ Ethanol & Room temperature & 11 \\
2 & $\mathrm{NaBH}_{4} /$ Ethanol & $0{ }^{\circ} \mathrm{C}$ & 25 \\
3 & $\mathrm{NaBH}_{4} /$ Ethanol & $-30{ }^{\circ} \mathrm{C}$ & 20 \\
4 & $\mathrm{NaBH}_{3} \mathrm{CN} /$ Methanol & Room temperature & 10 \\
5 & $\mathrm{LiAlH}_{4} /$ Diethyl ether & $0{ }^{\circ} \mathrm{C}$ & 15 \\
6 & L-Selectride/THF & $-78{ }^{\circ} \mathrm{C}$ & 12 \\
7 & L-Selectride/THF & $-78{ }^{\circ} \mathrm{C}$ to room temperature & 12 \\
\hline
\end{tabular}

${ }^{\mathrm{a}}$ In all cases the starting material sulfolane $\mathbf{1}$ was added as a diastereomerically pure sample; ${ }^{\mathrm{b}}$ Yields quoted are following purification by column chromatography on silica gel.

Furthermore, the product 2 also displayed poor diastereocontrol. A mixture of three diastereomers in the ratio 61:23:16 $\left(\mathrm{NaBH}_{4} /\right.$ Ethanol mediated reduction at $0{ }^{\circ} \mathrm{C}$ (Table 1, entry 2)) was evident in the ${ }^{1} \mathrm{H}$ NMR spectrum of the crude material. Following purification of this sample by column chromatography, only two of the isomers were detected $\mathbf{2 a}$ and $\mathbf{2} \mathbf{b}$, and isolated as an inseparable mixture in the ratio 67:33 (Scheme 2). The poor efficiency and diastereoselectivity of the chemical mediated reduction was unprecedented as previously reported sodium borohydride reductions of the $\beta$-keto sulfones had 
resulted in quantitative recovery of the required alcohols [8-10]. Relative stereochemistry on the sulfolane ring of the diastereomers $\mathbf{2 a}$ and $\mathbf{2 b}$, was tentatively assigned by ${ }^{1} \mathrm{H}$ NMR spectral analysis however it was not possible to identify the relative stereochemistry at the hydroxyl centre. It is clear on the basis of the diastereomeric mixture recovered that partial epimerization of $\mathbf{1}$ to the corresponding cis isomer occurs in the reaction medium prior to reduction. As the $\beta$-keto sulfone is relatively acidic, interconversion of the cis and trans isomers is readily rationalized.

Scheme 2. Sodium borohydride reduction of trans-2-acetyl-3-methyl sulfolane $\mathbf{1}$.

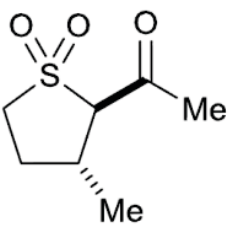

1

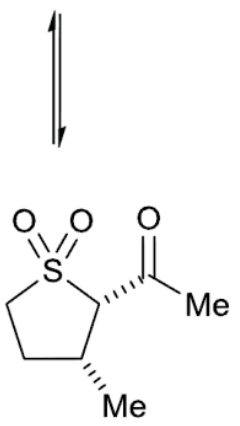

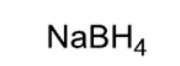
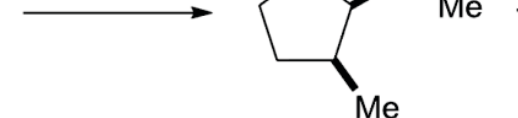

$2 a$

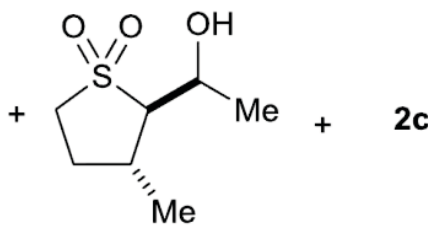

2b

2a : 2b: 2c

d.r. (crude) $61: 23: 16$

d.r. (pure) $67: 33: 0$ Yield $25 \%$

Clearly the conventional chemical route to the alcohol $\mathbf{2}$ is not synthetically practical; accordingly, the baker's yeast mediated reduction of trans-2-acetyl-3-methyl sulfolane $\mathbf{1}$ was next explored.

\subsection{Baker's Yeast Reduction of trans-2-Acetyl-3-methyl Sulfolane 1}

The baker's yeast mediated biocatalytic reduction of trans-2-acetyl-3-methyl sulfolane $\mathbf{1}$ was conducted employing a suspension of baker's yeast and sucrose in tap water at room temperature. The yeast reduction proceeded efficiently with two diastereomeric alcohols $\mathbf{2 a}$ and $\mathbf{2 b}(67 \%$ combined pure yield) and only a trace of starting material 1 (7\% pure yield) isolated from the crude reaction mixture following purification by column chromatography (Scheme 3). This is in direct contrast to the chemical reduction of $\mathbf{1}$ which yielded a crude mixture of three diastereomers and a very poor recovery of the diastereomeric alcohols $\mathbf{2} \mathbf{a}$ and $\mathbf{2} \mathbf{b}$ following purification ( $25 \%$ combined pure yield).

The baker's yeast mediated reduction of trans-2-acetyl-3-methyl sulfolane $\mathbf{1}$ yielded two diastereomers $\mathbf{2} \mathbf{a}$ and $\mathbf{2} \mathbf{b}$, isolated in the ratio 40:60. It is clear that in the yeast medium the cis and trans isomers of the sulfolane 1 interconvert via enolisation (Scheme 4). The yeast reductases selectively reduce these sulfolanes to form two diastereomeric alcohols, presumably reacting selectively with the ketone isomers bearing the same absolute stereochemistry at C-2. The yeast enzymes do not appear to distinguish the sterocentre at C-3. While the stereochemistry at C-2 and C-3 of the two diastereomers was not definitively confirmed in the study, based on Prelog's rule $S$-configuration at the newly generated stereogenic hydroxyl centre is envisaged in each case [19]. 
Scheme 3. Baker's yeast and $\mathrm{NaBH}_{4}$ reduction of trans-2-acetyl-3-methyl sulfolane $\mathbf{1}$.

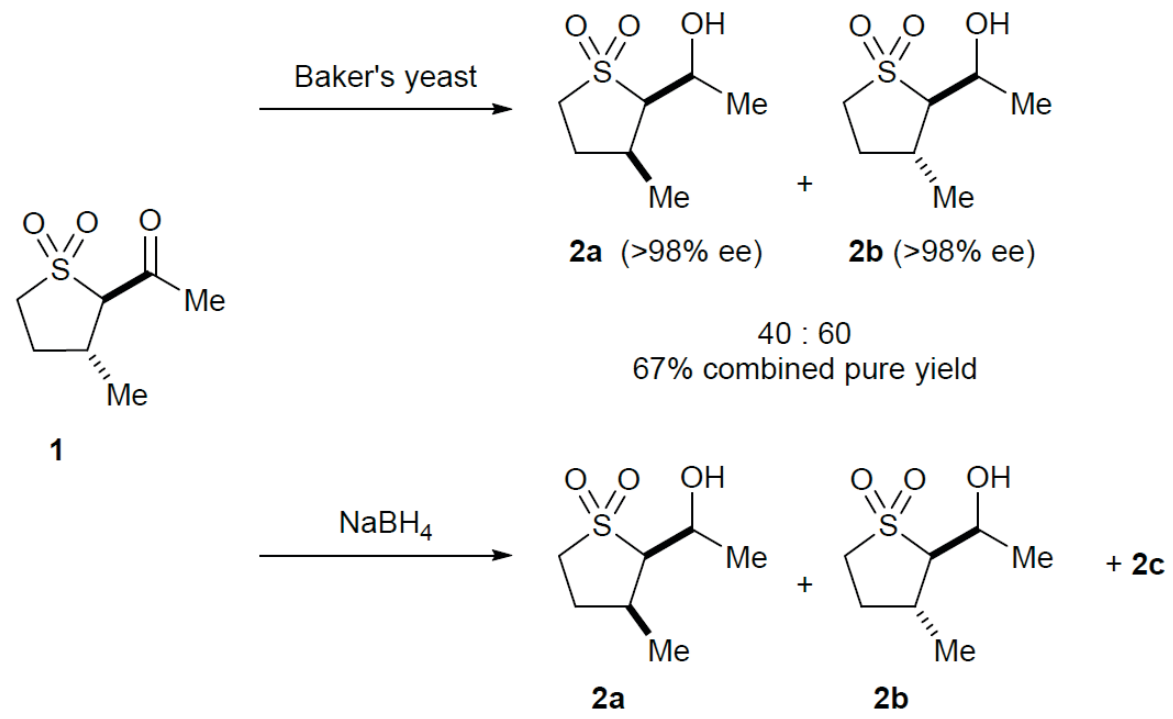

$2 \mathrm{a}: 2 \mathrm{~b}: \mathbf{2 c}$

d.r. (crude) $61: 23: 16$

d.r. (pure) $67: 33: 0$

$25 \%$ combined pure yield of $\mathbf{2 a}$ and $\mathbf{2 b}$

Scheme 4. Baker's yeast reduction of trans-2-acetyl-3-methyl sulfolane $\mathbf{1}$.
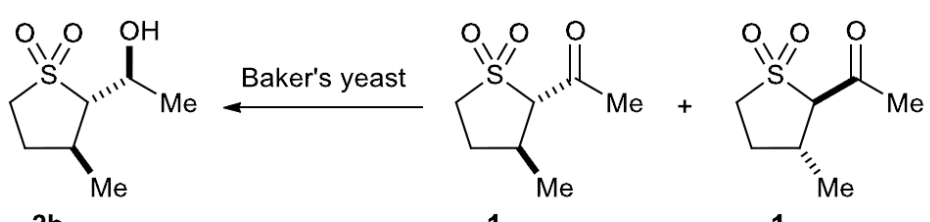

1
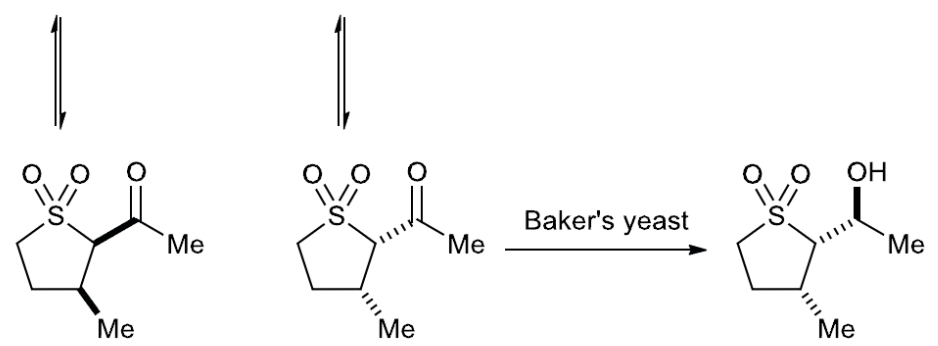

$2 a$

A number of strategies have been reported in the literature to improve the diastereoselectivity of baker's yeast, namely action of irreversible enzyme inhibitors [20-23], addition of organic solvents [24], cell immobilization [25-27], chemical modification of the substrate [28], pre-treatment of the cellular mass [29] and addition of sulfur compounds to the reaction mixture [30]. Interestingly, the diastereocontrol of the microbial reduction was opposite to the borohydride reduction, the principal isomer isolated being $\mathbf{2 b}$ as opposed to $\mathbf{2} \mathbf{a}$ in the chemical reduction.

Excellent enantiopurity of each of the generated alcohols $\mathbf{2 a}$ and $\mathbf{2} \mathbf{b}$ was attained $(>98 \%$ ee). ${ }^{1} \mathrm{H}$ NMR spectroscopy in the presence of the chiral shift reagent $\mathrm{Eu}(\mathrm{hfc})_{3}$, conducted on both racemic and enantiopure samples, determined that each of the products isolated $\mathbf{2 a}$ and $\mathbf{2} \mathbf{b}$ was enantiopure, demonstrating that baker's yeast was capable of effecting selective reduction. Thus, the sulfolane moiety can fit into the active site of the yeast reductase to facilitate hydride delivery to the carbonyl group. 


\section{Experimental Section}

\subsection{General}

All solvents were dried and distilled prior to use. Organic phases were dried using anhydrous magnesium sulfate. 4-Toluenesulfonyl azide was prepared using extreme care from 4-toluenesulfonyl chloride and sodium azide in aqueous acetone [31]. In the baker's yeast reductions, the sucrose employed was obtained from Siúcra Irish Granulated Sugar (Dublin, Ireland); the antifoam solution employed was Antifoam 289 (pfs) (Gillingham, UK) mixed solution. Ordinary tap water was used as solvent and Sigma (Gillingham, UK) type II baker's yeast (BY; Saccharomyces cerivisae) was employed. All reactions were carried out under an inert atmosphere. ${ }^{1} \mathrm{H}(300 \mathrm{MHz})$ and ${ }^{13} \mathrm{C}$ (75.5 MHz) NMR spectra were recorded on a Bruker (Billerica, MA, USA) Avance 300 NMR spectrometer. All spectra were recorded at room temperature $\left(\sim 20{ }^{\circ} \mathrm{C}\right)$ in deuterated chloroform $\left(\mathrm{CDCl}_{3}\right)$, using tetramethylsilane (TMS) as an internal standard. Enantiomeric purity was determined by ${ }^{1} \mathrm{H}$ MMR spectroscopy $(300 \mathrm{MHz})$ in the presence of the chiral shift reagent tris[3-(heptafluoropropylhydroxymethylene)-(+)-camphorato] emporium(III) derivative [Eu(hfc) 3 , added portionwise using $\sim 8 \mathrm{~mol} \%$. Optical rotations were measured on a Perkin-Elmer (Waltham, MA, USA); 141 polarimeter at $589 \mathrm{~nm}$ in a $10 \mathrm{~cm}$ cell; concentrations (c) are expressed in $\mathrm{g} / 100 \mathrm{~mL}$.

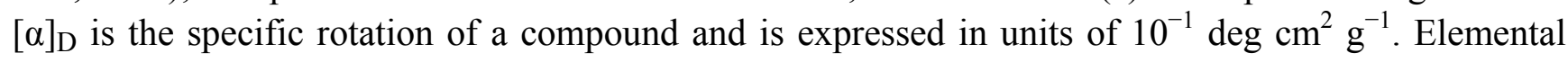
analysis was performed by the Microanalysis Laboratory, National University of Ireland, Cork, using Perkin-Elmer (Waltham, MA, USA); 240 elemental analyser. Melting points were carried out on a uni-melt Thomas Hoover Capillary (Philadelphia, PA, USA) melting point apparatus and are uncorrected. Infrared spectra were recorded as thin films on sodium chloride plates for oils or as potassium bromide $(\mathrm{KBr})$ discs for solids on a Perkin Elmer (Dublin, Ireland); Paragon 1000 FT-IR spectrometer. 1-(Butanethio)propan-2-one 4 and 1-(butanesulfonyl)propan-2-one 5 have previously been reported in the literature [16,17].

\subsection{1-(Butanesulfonyl)-1-diazopropan-2-one 6}

Potassium carbonate ( $1.52 \mathrm{~g}, 11.00 \mathrm{mmol}$ ) was added to a stirring solution of 1-(butanesulfonyl)propan2-one $5(1.78 \mathrm{~g}, 10.00 \mathrm{mmol})$ in acetonitrile $(15 \mathrm{~mL})$ at room temperature. The reaction mixture was stirred at room temperature for $10 \mathrm{~min}$ and then cooled to $0{ }^{\circ} \mathrm{C}$ by immersion of the reaction mixture into an ice-bath. A solution of 4-toluenesulfonyl azide $(2.13 \mathrm{~g}, 10.80 \mathrm{mmol})$ in acetonitrile $(15 \mathrm{~mL})$ was added dropwise over $5 \mathrm{~min}$. The reaction mixture was stirred for $2 \mathrm{~h}$ at $0{ }^{\circ} \mathrm{C}$ during which time the solution changed to orange in colour. Diethyl ether $(20 \mathrm{~mL})$ was then added to precipitate the insoluble salts. The orange suspension was filtered through a bed of Celite ${ }^{\circledR}$ (Sigma-Aldrich, Gillingham, UK) and washed with diethyl ether $(10 \mathrm{~mL})$. The filtrate was dried and concentrated at reduced pressure. A solution of hexane and diethyl ether $(30 \mathrm{~mL}, 2: 1)$ was added to the resulting residue and the mixture was stirred for $30 \mathrm{~min}$. The resulting solution was filtered and the yellow filtrate was dried and concentrated at reduced pressure to give the crude diazo compound $\mathbf{6}$. Purification of this crude product by column chromatography on silica gel using ethyl acetate-hexane (30:70) as eluent gave 1-(butanesulfonyl)-1-diazopropane-2-one $6(1.20 \mathrm{~g}, 59 \%)$ as a yellow oil; $v_{\max } / \mathrm{cm}^{-1}$ (film) 2117, 1667, 1332, 1139; $\delta_{\mathrm{H}}\left(\mathrm{CDCl}_{3}, 300 \mathrm{MHz}\right) 0.97\left(3 \mathrm{H}, \mathrm{t}, J=7 \mathrm{~Hz}, \mathrm{CH}_{3}-4^{\prime}\right), 1.41-1.58(2 \mathrm{H}$, sym m, $J=7 \mathrm{~Hz}$, 
$\left.\mathrm{CH}_{2}-3^{\prime}\right), 1.77-1.90\left(2 \mathrm{H}, \mathrm{m}, \mathrm{CH}_{2}-2^{\prime}\right) 2.39\left(3 \mathrm{H}, \mathrm{s}, \mathrm{COCH}_{3}\right), 3.31-3.39\left(2 \mathrm{H}, \mathrm{m}, \mathrm{CH}_{2} \mathrm{SO}_{2}\right) ; \delta_{\mathrm{C}}\left(\mathrm{CDCl}_{3}\right.$, $75.5 \mathrm{MHz}) 13.54\left(\mathrm{CH}_{3}, \mathrm{CH}_{3}\right), 21.34\left(\mathrm{CH}_{2}, \mathrm{CH}_{2}-3{ }^{\prime}\right), 24.70\left(\mathrm{CH}_{2}, \mathrm{CH}_{2}-2^{\prime}\right), 27.00\left(\mathrm{CH}_{3}, \mathrm{COCH}_{3}\right), 57.42$ $\left(\mathrm{CH}_{2}, \mathrm{CH}_{2} \mathrm{SO}_{2}\right), 90.12(\mathrm{C}, \mathrm{CO})$.

\section{3. trans-1-(3-Methyl-1,1-dioxo-tetrahydro-1 $\lambda^{6}$-thiophen-2-yl)ethanone 1}

Rhodium(II) trifluoroacetamide $(0.5 \mathrm{mg}, 0.82 \mu \mathrm{mol}, 0.05 \mathrm{~mol} \%)$ was added to a refluxing solution of 1-(butanesulfonyl)-1-diazopropan-2-one 6 (300 mg, $1.47 \mathrm{mmol})$ in dichloroethane $(10 \mathrm{~mL})$. The progress of the reaction was monitored by IR spectroscopy, where reaction completion was indicated by the disappearance of the characteristic diazo peak at $2117 \mathrm{~cm}^{-1}, c a .12 \mathrm{~h}$. Upon reaction completion, the reaction mixture was cooled and evaporation of the reaction solvent at reduced pressure gave the crude product. Purification by column chromatography on silica gel using ethyl acetate-hexane (30:70) as eluent gave the pure sulfolane product $\mathbf{1}(106 \mathrm{mg}, 41 \%)$ as a pale yellow solid, tentatively assigned as the trans-isomer (>98:2 d.r.); m.p. $53-55{ }^{\circ} \mathrm{C}$; Found $\mathrm{C}, 47.83 ; \mathrm{H}, 6.98 ; \mathrm{S}, 18.01 . \mathrm{C}_{7} \mathrm{H}_{12} \mathrm{SO}_{3}$ requires $\mathrm{C}, 47.71 ; \mathrm{H}, 6.86 ; \mathrm{S}, 18.20 ; v_{\max } / \mathrm{cm}^{-1}(\mathrm{KBr}) 2959,1721,1317,1126 ; \delta_{\mathrm{H}}\left(\mathrm{CDCl}_{3}, 300 \mathrm{MHz}\right) 1.15(3 \mathrm{H}$, $\left.\mathrm{d}, J=6.5 \mathrm{~Hz}, \mathrm{CH}_{3}\right), 1.68-1.88\left(1 \mathrm{H}, \mathrm{m}, H_{A}\right.$ of $\left.\mathrm{CH}_{2}-4\right), 2.25-2.37\left(1 \mathrm{H}, \mathrm{m}, H_{B}\right.$ of $\left.\mathrm{CH}_{2}-4\right), 2.43(3 \mathrm{H}, \mathrm{s}$, $\left.\mathrm{COCH}_{3}\right), 2.76-2.82(1 \mathrm{H}$, sym $\mathrm{m}, J=6 \mathrm{~Hz}, \mathrm{CHMe}), 3.03-3.17\left(1 \mathrm{H}, \mathrm{m}, H_{A}\right.$ of $\left.\mathrm{CH}_{2}-5\right), 3.28-3.37(1 \mathrm{H}$, m, $H_{B}$ of $\left.\mathrm{CH}_{2}-5\right), 3.68\left(1 \mathrm{H}, \mathrm{d}, J=10 \mathrm{~Hz}, \mathrm{SO}_{2} \mathrm{CHCO}\right) ; \delta_{\mathrm{C}}\left(\mathrm{CDCl}_{3}, 75.5 \mathrm{MHz}\right) 19.12\left(\mathrm{CH}_{3}\right), 28.12$, 31.59, $33.44\left(\mathrm{CH}_{2}-4, C \mathrm{HMe}\right.$ and $\left.\mathrm{COCH}_{3}\right), 53.39\left(\mathrm{CH}_{2} \mathrm{SO}_{2}\right), 77.64\left(\mathrm{SO}_{2} \mathrm{CHCO}\right), 197.24(\mathrm{CO})$.

\subsection{Reduction of 1 with Sodium Borohydride}

1-(3-Methyl-1,1-dioxo-tetrahydro-1 $\lambda^{6}$-thiophen-2-yl)ethanol 2

The trans-2-acetyl-3-methyl sulfolane 1 (100 mg, $0.57 \mathrm{mmol})$ (>98:2 d.r.) in ethanol (10 mL) was added dropwise over $5 \mathrm{~min}$ to a suspension of sodium borohydride (39 $\mathrm{mg}, 1.02 \mathrm{mmol}$ ) in ethanol $(10 \mathrm{~mL})$ at $0{ }^{\circ} \mathrm{C}$. The reaction mixture was stirred for $50 \mathrm{~min}$ at this temperature and then the ice bath was removed. Water was added $(10 \mathrm{~mL})$ to the reaction mixture and it was then concentrated at reduced pressure. The resulting residue was partitioned between diethyl ether $(20 \mathrm{~mL})$ and water $(10 \mathrm{~mL})$, the layers were separated and the aqueous layer was extracted with diethyl ether $(3 \times 5 \mathrm{~mL})$. The combined organic layers were washed with brine $(20 \mathrm{~mL})$, dried and concentrated at reduced pressure to give the crude alcohol 2. A ${ }^{1} \mathrm{H}$ NMR spectrum of the crude sample was recorded and showed the presence of a mixture of three isomers (61:23:16 d.r.), as determined by characteristic signals at $\delta_{\mathrm{H}} 3.91-4.07(61 \%), \delta_{\mathrm{H}} 4.17-4.26(16 \%)$ and $\delta_{\mathrm{H}} 4.43-4.52(23 \%)$. Purification of this crude product by chromatography on silica gel using ethyl acetate-hexane (50:50) as eluent gave 2 (26 mg, $25 \%$ ) as a colourless oil and as an inseparable mixture of two diastereomers, cis-2-ethanol-3-methyl sulfolane $\mathbf{2 a}$ and trans-2-ethanol-3-methyl sulfolane $\mathbf{2 b}$, (67:33 d.r.) which was contaminated with a trace amount $(\sim 8 \%)$ of an unidentified impurity; $v_{\max } / \mathrm{cm}^{-1}(\mathrm{KBr}) 3500,1312,1125 ; \delta_{\mathrm{H}}\left(\mathrm{CDCl}_{3}\right.$, $300 \mathrm{MHz}) 1.22\left(2.01 \mathrm{H}, \mathrm{d}, J=6, \mathrm{CH}_{3}-3\right.$ of $\left.\mathbf{2 a}\right), 1.28\left(0.99 \mathrm{H}, \mathrm{d}, J=7\right.$, one of $\mathrm{CH}_{3}$ of $\left.\mathbf{2 b}\right), 1.32(0.99 \mathrm{H}$, $\mathrm{d}, J=7 \mathrm{~Hz}$, one of $\mathrm{CH}_{3}$ of $\left.\mathbf{2 b}\right), 1.51\left(2.01 \mathrm{H}, \mathrm{d}, J=7 \mathrm{~Hz}, \mathrm{CH}(\mathrm{OH}) \mathrm{CH}_{3}\right.$ of $\left.2 \mathbf{a}\right), 1.68-1.82(1 \mathrm{H}$, one of $\left.\mathrm{CH}_{2}-4\right), 2.20-2.32\left(1 \mathrm{H}, \mathrm{m}\right.$, one of $\left.\mathrm{CH}_{2}-4\right), 2.33-2.47(0.67 \mathrm{H}$, sym $\mathrm{m}, J=6 \mathrm{~Hz}, \mathrm{CHMe}$ of 2a), 2.51-2.73 $\left(1.33 \mathrm{H}, \mathrm{m}\right.$, one of $\mathrm{CH}_{2}-5$ and $\mathrm{CHMe}$ of $\left.\mathbf{2 b}\right), 2.82-3.07\left(1 \mathrm{H}, \mathrm{m}, \mathrm{SO}_{2} \mathrm{CH}\right), 3.07-3.25(1 \mathrm{H}, \mathrm{m}$, one of $\left.\mathrm{CH}_{2}-5\right), 3.96-4.08(0.67 \mathrm{H}, \mathrm{m}, \mathrm{CHOH}$ of $\mathbf{2 a}), 4.47(0.33 \mathrm{H}, \mathrm{dq}, J=7 \mathrm{~Hz},<1, \mathrm{CHOH}$ of $2 \mathbf{b})$; 
Major diastereomer, 1; $\delta_{\mathrm{C}}\left(\mathrm{CDCl}_{3}, 75.5 \mathrm{MHz}\right) 19.6\left(\mathrm{CH}_{3}, \mathrm{CH}_{3}\right), 21.60\left(\mathrm{CH}_{3}, \mathrm{CH}(\mathrm{OH}) \mathrm{CH}_{3}\right), 29.05$ $\left(\mathrm{CH}_{2}, \mathrm{CH}_{2}-4\right), 34.57(\mathrm{CH}, \mathrm{CHMe}), 52.97\left(\mathrm{CH}_{2}, \mathrm{CH}_{2}-5\right), 66.22,73.39\left(\mathrm{CH}, \mathrm{CHOH}\right.$ and $\left.\mathrm{SO}_{2} \mathrm{CH}\right)$. Minor diastereomer, 2b; $\delta_{\mathrm{C}}\left(\mathrm{CDCl}_{3}, 75.5 \mathrm{MHz}\right) 20.89\left(\mathrm{CH}_{3}, \mathrm{CH}_{3}\right), 22.17\left(\mathrm{CH}_{3}, \mathrm{CH}(\mathrm{OH}) \mathrm{CH}_{3}\right), 29.05\left(\mathrm{CH}_{2}\right.$, $\left.\mathrm{CH}_{2}-4\right), 31.04(\mathrm{CH}, \mathrm{CHMe}), 51.93\left(\mathrm{CH}_{2}, \mathrm{CH}_{2}-5\right), 64.35,72.11\left(\mathrm{CH}, \mathrm{CHOH}\right.$ and $\left.\mathrm{SO}_{2} \mathrm{CH}\right)$.

\subsection{Reduction of 1 with Baker's Yeast}

1-(3-Methyl-1,1-dioxo-tetrahydro-1 $\lambda^{6}$-thiophen-2-yl)ethanol 2

A suspension of baker's yeast (Sigma, Type II, $10 \mathrm{~g})$, sucrose (10 g) and antifoam (2 drops) in tap water $(60 \mathrm{~mL})$ was shaken gently at $28{ }^{\circ} \mathrm{C}$ for $30 \mathrm{~min}$. trans-2-Acetyl-3-methyl sulfolane 1 (100 mg, $0.57 \mathrm{mmol})(>98: 2$ d.r.) in DMSO $(1.5 \mathrm{~mL})$ was added slowly over 1 minute and the mixture was shaken gently at $28{ }^{\circ} \mathrm{C}$ for $48 \mathrm{~h}$. Celite ${ }^{\circledR}(5 \mathrm{~g})$ (Sigma-Aldrich, Gillingham, UK) was then added and the mixture was stirred at room temperature for $30 \mathrm{~min}$. The yeast mixture was filtered through a pad of Celite ${ }^{\circledR}$ and washed with water $(50 \mathrm{~mL})$ and ethyl acetate $(50 \mathrm{~mL})$. The filtrate was separated and the aqueous layer was saturated with sodium chloride and extracted with ethyl acetate $(3 \times 100 \mathrm{~mL})$. The organic layers were combined and washed with brine $(75 \mathrm{~mL})$, dried and concentrated at reduced pressure to give the crude alcohol 2 as a yellow oil. Purification by column chromatography on silica gel using ethyl acetate-hexane (35:75) as eluent gave the unreacted trans-2-acetyl-3-methyl sulfolane 1 (7 mg, 7\%) and an inseparable mixture of cis-2-ethanol-3-methyl sulfolane 2a and trans-2-ethanol-3methyl sulfolane $\mathbf{2 b}(62 \mathrm{mg}, 61 \%)$ as a colourless oil, $40: 60$ d.r.: $[\alpha]_{\mathrm{D}}+19^{\circ}\left(\mathrm{c} 1, \mathrm{CHCl}_{3}\right) ;>98 \%$ ee. for each diastereomer (as determined by ${ }^{1} \mathrm{H} N M R$ in the presence of $\mathrm{Eu}(\mathrm{hfc})_{3}$ ). Spectral characteristics of the ethanone $\mathbf{1}$ and ethanol products $\mathbf{2 a}$ and $\mathbf{2 b}$ were in agreement with those of the racemic compounds.

\section{Conclusions}

In summary, the chemical reduction of 2-acetyl-3-methyl sulfolane $\mathbf{1}$ was not synthetically practical as the reduction proceeded with poor efficiency and diastereoselectivity. Significantly, efficient reduction of 1 was achieved utilising mild baker's yeast mediated reaction conditions providing the corresponding diastereomeric alcohols $\mathbf{2} \mathbf{a}$ and $\mathbf{2 b}$ in excellent enantiopurity ( $>98 \%$ ee) and good yield (67\%). Thus, in this instance biocatalysis offers a higher degree of selectivity and efficiency relative to its conventional chemical counterpart. The enantiomerically pure alcohols $\mathbf{2 a}$ and $\mathbf{2 b}$ are valuable chiral synthons in synthesis, as both the hydroxyl and sulfonyl moieties are synthetically versatile.

\section{Acknowledgments}

This publication has emanated from research conducted with the financial support of: IRCSET and Eli Lilly (RED) and Enterprise Ireland, BioResearch Ireland and University College Cork, especially the President's Research Fund (NOR). 


\section{Author Contributions}

This work is part of the $\mathrm{PhD}$ thesis of Noreen O'Riordan who carried out the experimental studies under the supervision of Anita R. Maguire who provided the concept and guidance. Rebecca E. Deasy prepared the manuscript and revised it.

\section{Conflicts of Interest}

The authors declare no conflict of interest.

\section{References}

1. Santaniello, E.; Ferraboschi, P.; Grisenti, P.; Manzocchi, A. The biocatalytic approach to the preparation of enantiomerically pure chiral building blocks. Chem. Rev. 1992, 92, 1071-1140.

2. Nakamura, K.; Yamanaka, R.; Matsuda, T.; Harada, T. Recent developments in asymmetric reduction of ketones with biocatalysts. Tetrahedron 2003, 14, 2659-2681.

3. Csuk, R.; Glaenzer, B.I. Baker's yeast mediated transformations in organic chemistry. Chem. Rev. 1991, 91, 49-97.

4. Servi, S. Baker's yeast as a reagent in organic synthesis. Synthesis 1990, 1-25.

5. Poppe, L.N.L. Selective Biocatalysis; VCH: New York, NY, USA, 1992.

6. Sato, T.; Fujisawa, T. Stereocontrol in bakers' yeast reduction leading to natural product synthesis. Biocatalysis 1990, 3, 1-15.

7. Deasy, R.E.; Maguire, A.R. Baker's-yeast-mediated reduction of sulfur-containing compounds. Eur. J. Org. Chem. 2014, doi:10.1002/ejoc.201301729.

8. Maguire, A.R.; O'Riordan, N. Dynamic kinetic resolution in the bakers' yeast mediated reduction of 2-benzenesulfonylcycloalkanones. Tetrahedron Lett. 1999, 40, 9285-9288.

9. Maguire, A.R.; Kelleher, L.L.; Ferguson, G. Efficient kinetic resolution of 2-benzenesulfonylcyclopentanone derivatives. J. Mol. Catal. B 1996, 2, 147-158.

10. Maguire, A.R.; Kelleher, L.L. Enantioselective introduction of a benzenesulfonylmethyl substituent at an unactivated carbon atom via chemoenzymic methods. Tetrahedron Lett. 1997, $38,7459-7462$.

11. Yao, Q. Synthesis of cyclic sulfones by ring-closing Metathesis. Org. Lett. 2002, 4, 427-430.

12. Buynak, J.D.; Vogeti, L.; Chen, H. Coupling reactions of cephalosporin sulfones: A stable 3-stannylated cephem. Org. Lett. 2001, 3, 2953-2956.

13. Ghosh, A.K.; Thompson, W.J.; Munson, P.M.; Liu, W.; Huff, J.R. Cyclic sulfone-3-carboxamides as novel P2-ligands for Ro 31-8959 based HIV-1 protease inhibitors. Bioorg. Med. Chem. Lett. 1995, 5, 83-88.

14. Kim, C.U.; McGee, L.R.; Krawczyk, S.H.; Harwood, E.; Harada, Y.; Swaminathan, S.; Bischofberger, N.; Chen, M.S.; Cherrington, J.M. New series of potent, orally bioavailable, non-peptidic cyclic sulfones as HIV-1 protease inhibitors. J. Med. Chem. 1996, 39, 3431-3434.

15. Richter, H.G.F.; Angehrn, P.; Hubschwerlen, C.; Kania, M.; Page, M.G.P.; Specklin, J.L.; Winkler, F.K. Design, synthesis, and evaluation of 2beta-alkenyl penam sulfone acids as inhibitors of beta-lactamases. J. Med. Chem. 1996, 39, 3712-3722. 
16. Lissel, M. Phase-transfer catalytic preparation of $\alpha$-alkylthio or $\alpha$-arylthio carbonyl compounds. J. Chem. Res. Synop. 1982, 10, 286.

17. Fehnel, E.A.; Carmack, M. Ultraviolet absorption spectra of organic sulfur compounds. 11. compounds containing the sulfone function. J. Am. Chem. Soc. 1949, 71, 231-237.

18. Monteiro, H.J. Synthesis of $\alpha$-(phenylsulfonyl)cyclopentanones by intramolecular carbenoid cyclization of $\alpha$-diazo- $\beta$-keto phenyl sulfones. Tetrahedron Lett. 1987, 28, 3459-3462.

19. Prelog, V. Specification of the stereospecificity of some oxidoreductases by diamond lattice sections. Pure Appl. Chem. 1964, 9, 119-130.

20. Fow, K.L.; Poon, L.C.H.; Sim, S.T.; Chuah, G.K.; Jaenicke, S. Enhanced asymmetric reduction of ethyl 3-oxobutyrate by baker's yeast via substrate feeding and enzyme inhibition. Eng. Life Sci. 2008, 8, 372-380.

21. Ushio, K.; Hada, J.; Tanaka, Y.; Ebara, K. Allyl bromide, a powerful inhibitor against R-enzyme activities in bakers' yeast reduction of ethyl 3-oxoalkanoates. Enzyme Microb. Technol. 1993, 15, 222-228.

22. Sybesma, W.F.H.; Straathof, A.J.J.; Jongejan, J.A.; Pronk, J.T.; Heijnen, J.J. Reductions of 3-oxo esters by baker's yeast: Current status. Biocatal. Biotransform. 1998, 16, 95-134.

23. Dahl, A.C.; Fjeldberg, M.; Madsen, J.O. Baker's yeast: Improving the D-stereoselectivity in reduction of 3-oxo esters. Tetrahedron: Asymm. 1999, 10, 551-559.

24. Engelking, H.; Pfaller, R.; Wich, G.; Weuster-Botz, D. Reaction engineering studies on $\hat{I}^{2}$-ketoester reductions with whole cells of recombinant Saccharomyces cerevisiae. Enzyme Microb. Technol. 2006, 38, 536-544.

25. Nakamura, K.; Higaki, M.; Ushio, K.; Oka, S. Stereochemical control of microbial reduction. 2. Reduction of $\hat{I}^{2}$-keto esters by immobilized bakers' yeast. Tetrahedron Lett. 1985, 26, 4213-4216.

26. Naoshima, Y.; Hasegawa, H. Synthesis of both enantiomers of phoracantholide I, a defensive secretion of the eucarypt longicorn Phoracantha synonyma, employing asymmetric reduction with immobilized bakers' yeast. Chem. Lett. 1987, 2379-2382.

27. Lin, Y.H.; Hwang, S.C.J.; Shih, W.C.; Chen, K.C. Development of a novel microorganism immobilization method using anionic polyurethane. J. Appl. Polym. Sci. 2006, 99, 738-743.

28. Nakamura, K.; Ushio, K.; Oka, S.; Ohno, A.; Yasui, S. Stereochemical control in yeast reduction. Tetrahedron Lett. 1984, 25, 3979-3982.

29. Vitinius, U.; Schaffner, K.; Demuth, M. New strategies improve the efficiency of the baker's yeast reduction of ketoesters: near UV irradiation and a two-substrate application. J. Photochem. Photobiol. A 2005, 169, 197-210.

30. Hayakawa, R.; Nozawa, K.; Shimizu, M.; Fujisawa, T. Control of enantioselectivity in the bakers' yeast reduction of $\beta$-keto ester derivatives in the presence of a sulfur compound. Tetrahedron Lett. 1998, 39, 67-70.

31. Curphey, T.J. Preparation of $p$-toluenesulfonyl azide. A cautionary note. Org. Prep. Proced. Int. 1981, 13, 112-115.

(C) 2014 by the authors; licensee MDPI, Basel, Switzerland. This article is an open access article distributed under the terms and conditions of the Creative Commons Attribution license (http://creativecommons.org/licenses/by/3.0/). 